\title{
NEGAÇÃO DO HOMEM, AFIRMAÇÃO DA POLÍTICA: NICOLAU MAQUIAVEL E A POLITICIDADE MODERNA
}

\author{
Paola Baldovinotti Serpa ${ }^{1}$
}

\begin{abstract}
RESUMO
Neste artigo abordamos a concepção política de Nicolau Maquiavel (1469-1527) enfatizando seu caráter peculiar a partir das condições históricas que o determina. É, pois, a voz mais expressiva das contradições e tensões próprias da transição renascentista. 0 panorama inaugural da modernidade - isto é, a emergência do capital e suas exigências particulares é captado e traduzido pelo pensador florentino numa síntese que põe em razão direta a negação do homem e a afirmação da política, admitindo irrestrita a soberania do Estado em função da degenerescência inata dos homens.
\end{abstract}

Palavras-chave: Politicidade moderna. Transição capitalista. Egoísmo universal. Poder.

\section{DENIAL MAN, AFFIRMATION OF POLITICS: NICCOLO MACHIAVELLI AND THE MODERN POLITICY}

\begin{abstract}
This article discusses the political conception of Niccolò Machiavelli (1469-1527), emphasizing his peculiar character from the historical conditions that define him. It is, therefore, the most expressive voice of the contradictions and tensions inherent in the Renaissance transition. The inaugural scene of modernity - that is, the emergence of capital
\end{abstract}

\footnotetext{
1 Doutoranda em Ciências Sociais pela Universidade Estadual Paulista "Julio de Mesquita Filho" UNESP/Marília, Brasil.paola_serpa@ig.com.br
} 
and its particular requirements - is captured and translated by the Florentine thinker in a synthesis that puts in direct reason the denial of man and the affirmation of politics, admitting unrestricted state sovereignty due to the innate degeneracy of men.

Keywords: Modern political nature. Capitalist transition. Universal egoism. Power.

\section{INTRODUÇÃO}

0 revolucionamento da vida humana, num processo que abrangeu desde a esfera social e econômica até o domínio da cultura em seu sentido mais amplo, configurou uma das características mais exuberantes do cotidiano renascentista. 0 Renascimento é, assim, uma quadra histórica em constante convulsão, que oscilava entre a crise das antigas certezas da estabilidade natural das relações feudais e a expansão avassaladora do capital em sua fase de acumulação primitiva. É, pois, das próprias entranhas do feudalismo que as relações capitalistas começam a se desenvolver, de modo que 0 movimento de suplantar a coexistência subordinada das práticas capitalistas coincide com o de corrosão interna e implosão do sistema feudal.

Certamente essas transformações se processaram com força e intensidade distintas nos diversos locais do velho continente, e apesar desta determinação histórica constar aqui apenas como indicação, faz referir, também em termos gerais, aos destinos distintos dessas revoluções individuais em países mais decisivos. Na Itália, por exemplo, onde a cultura renascentista, além de ter seu efetivo início, desenvolve- se do modo mais clássico, acaba por se encontrar num impasse. Lá, (tal qual na Espanha e em parte da Holanda) as transformações em ritmo acelerado, ao contrário de concluir o processo de desenvolvimento iniciado, culminando num novo modo de produção, refluem à feudalidade. Mesmo onde esse processo desdobrou-se até as últimas consequências como na Inglaterra, pátria do processo clássico de objetivação do capitalismo verdadeiro - as faces do progresso vislumbradas com a revolução industrial revelaram-se muito mais problemáticas e contraditórias do que pareceram sob a aurora renascentista.

Estamos diante, portanto, das possibilidades reais de evolução social, no sentido da superação da já arcaica rede de relações feudais, e as que efetivamente se sucederam. Diferentemente de Inglaterra e França, que levam a cabo o movimento iniciado no Renascimento, a Itália vê seu desenvolvimento retrair-se, a partir do desencadeamento de um processo de refeudalização que pesará sobremaneira em sua história futura. Para nós, isto é de suma importância, pois a intelecção da particularidade italiana terá implicações diretas nas formulações de Maquiavel. 
Enfim, nesta breve introdução, atentamos para o fato de que, onde quer que começassem a surgir essas raízes da modernidade, a relação natural entre o indivíduo e a comunidade (os elos naturais que ligavam o homem à sua família, à sua situação social e o seu lugar previamente definido na sociedade) era paulatinamente destruída, abalando toda a hierarquia e a estabilidade das relações sociais existentes até então.

Num dado momento dos Grundrisse Marx compara a "comunidade natural" e a sociabilidade que se põe com o desenvolvimento capitalista - e nelas, os respectivos tipos de indivíduos pertencentes a cada uma. Em sua análise evidencia que a limitação histórica da evolução das forças produtivas, "tanto da riqueza como da maneira de a criar", determina os limites da própria comunidade, bem como das individualidades que as integra. A reprodução desses meios específicos de produção e destes indivíduos/relações sociais é, a um só tempo, o objetivo desta comunidade, assim como a condição da produção. 0 desenvolvimento do capital implica precisamente na ruptura dessas barreiras e limitações, pondo em perspectiva o desenvolvimento universal das forças produtivas e da riqueza e, em consonância, a possibilidade do desenvolvimento universal do indivíduo. A superação dessas limitações ocorre tanto em termos práticos quanto ao nível da consciência, tornando o indivíduo "capaz de apreender a sua própria história como um processo e de conceber de maneira científica a natureza com a qual forma verdadeiramente um todo (o que lhe permite dominá-la na prática)" (MARX, 2011, p. 541-542).

Ademais, no Renascimento (séculos XIV-XVI) data-se apenas o aparecimento da produção burguesa, e em nível ainda relativamente baixo. 0 retrocesso (na direção de uma refeudalização) ou o congelamento do desenvolvimento social ainda eram tendências possíveis, pois o processo de reprodução constante da sociedade burguesa que de fato iria consumar as novas relações e cuja explicitação cabal se põe a partir do século XVII - ainda não se iniciara. Isto implica que o Renascimento, mesmo sendo ponto de partida tanto da produção quanto da sociedade burguesas, "sua sociedade e modo de produção não eram ainda a própria sociedade e o próprio modo de produção burgueses." Em termos ideológicos, já era uma ideologia burguesa e de caráter revolucionário por ser "expressiva das novas relações sociais [que] veio combater a antiga". No entanto, "estava longe de se transformar na ideologia consciente de toda a burguesia; mais ainda, deixou os estratos plebeus praticamente intactos, enquanto, simultaneamente, lançava raízes e se desenvolvia entre a nobreza." (HELLER, 1982, p. 16-1, grifo do autor).

\section{MAQUIAVEL NA MODERNIDADE}

0 conhecimento de épocas passadas, não se nega, é fundamental para a elucidação dos tempos presentes. Não raro, no entanto, são as análises que 
comprometem essa aproximação, por vezes até corrompendo seu real significado, pelo fato de a avaliação ser pautada por critérios contemporâneos. 0 pensamento de Maquiavel e a compreensão de suas teorias, também estão suscetíveis a tal deformação. $\mathrm{Na}$ tentativa de não incorrer a tais equívocos, a sugestão de situá-lo como "o último grande pensador da república antiga e o primeiro do absolutismo moderno" (CHASIN, 2000, p. 202), ao mesmo tempo que contribui para evitar uma iniciação duvidosa, instiga a refletir sobre seu efetivo significado. É pertinente encará-lo como expressão das tensões entre o novo e o velho que forcejavam em sua época. 0 Renascimento é um momento histórico híbrido, altamente contraditório, ainda vacilante quanto ao rumo a se seguir; não haveria de ser diferente o caráter das formações ideais que emanaram dessa realidade.

Nessa mesma direção argumenta Gramsci, afirmando que "é necessário considerar Maquiavel, em grau maior, como expressão necessária de seu tempo e como estreitamente ligado às condições e às exigências de sua época.” E após sintetizar as determinações dessa realidade, ratifica sua convicção de que a ciência política de Maquiavel está em plena consonância com a filosofia da época, a qual tende "à organização das monarquias nacionais absolutas, a forma política que permite e facilita um novo desenvolvimento das forças produtivas burguesas." (GRAMSCI, 2007, p. 2930).

Se a filosofia e a ciência política tendem ao absolutismo é porque a própria realidade tem seu evolver em direção ao governo centralizado, sob o domínio de um único soberano. A partir de meados do século XV essas forças gerais se evidenciavam, e já em princípios do século XVI a monarquia absoluta era o tipo predominante de governo na Europa ocidental - vide Espanha, Inglaterra, mesmo a "Alemanha" (com Prússia e Áustria) e - a típica nação absolutista - a França. A tendência geral era, enfim, superar a dispersão territorial e a fragmentação dos círculos de autoridade, em que prevaleciam feudatários e corporações, que caracterizava o poder político nos moldes feudais.

E por que o absolutismo permite e facilita um novo desenvolvimento das forças produtivas burguesas?

Ao retrocedermos para o período mercantilista, que antecede a era industrial, verificamos que era no comércio de longa distância que se encontravam as transações financeiras e as técnicas capitalistas mais avançadas. Portanto, é o movimento do capital mercantil que nos interessa, particularmente as necessidades da sua persona o novo mercador. Este novo mercador forceja contra toda e qualquer forma de limitação: o comércio local lhe era medíocre, tanto quanto a pouca diversidade de mercadorias em circulação por rotas fixas, destinadas a portos e praças monopolizadas. Forcejava, portanto, por ampliar seus espaços de atuação, isto é, por ampliar sua lucratividade - o que envolvia lidar com qualquer produto vantajoso, em qualquer 
mercado de grande potencial. Era da esfera da troca, portanto, que provinham 0 estímulo econômico e os capitais que movimentavam a produção.

Ou seja, tais desdobramentos colocavam o mercador em posição dominante em relação ao artesão (o executor), garantindo ao primeiro o controle progressivo sobre a produção, na mesma medida em que, simultaneamente, subtraía poder dos antigos grêmios e cidades-repúblicas.

Assim, era uma necessidade vital para o típico mercador renascentista a livre circulação por territórios cada vez mais amplos, de modo que o poder absoluto será 0 grande fiador dessa expansão.

Numa palavra, a expansão mercantil demandava governos capazes de ampliar seu campo de ação para muito além dos perímetros municipais e do teor e âmbito que tipificavam a administração anterior. Necessitavam, em suma, de um governo forte, tanto para efeito interno quanto externo, donde a inclinação para 0 absolutismo - rei, príncipe ou senhor -, à custa de todos os freios e limitações que haviam cercado a monarquia medieval. Para essa nova categoria social, era factível fortalecer e articular com 0 monarca, e não procurar o então impossível domínio dos dispositivos parlamentares, controlados pela nobreza, de modo que não lhe custava nada sacrificar as formas de representação à monarquia. De fato, só se beneficiava com a restrição às disputas feudatárias e oligárquicas, numa palavra, da nobreza, que sustentava bandos de arruaceiros que intimidavam juízes e tribunais, e eram os instrumentos da violência endêmica gerada pelo entrechoque das facções clânicas. Para o novo mercador, a garantia da ordem pública, a concentração do poder militar e da administração de justiça nas mãos da coroa, o máximo possível, era um benefício fundamental, a verdadeira condição de possibilidade para a exercitação de seus propósitos (CHASIN, 2000, p. 204).

Reconhecer a modernidade do absolutismo, em seu tempo, bem como sua função civilizatória, é ponto de partida para determinar com precisão a abrangência do pensamento maquiaveliano. Mesmo porque, "ao se interpretar Maquiavel, ignora-se que a monarquia absoluta era, naquela época, uma forma de regime popular e que ela se apoiava nos burgueses contra os nobres e também contra o clero" (GRAMSCI, 2007, p. 75); ignora-se, portanto, que "o absolutismo do baixo Renascimento estava ligado por uma relação social real e sincera à ideologia do Renascimento [...] (HELLER, 1982, p. 18).

As possibilidades de expansão da potência humana marcam o dinamismo renascentista; não menos marcante é a dupla violência que se desdobra cotidianamente: por um lado, os ranços feudais ainda agrilhoam as relações sociais; por outro, simultaneamente, o individualismo desencadeado pela concorrência capitalista 
agudiza as oposições e disputas interindividuais. Por si mesmas, as nascentes relações burguesas de produção não eram capazes de suprimir a desordem feudal. Na verdade, ampliou as possibilidades de usar os mesmo meios, reiterando a prática individual da "justiça exercida pelas próprias mãos". Vejam com que "naturalidade" Maquiavel refere-se aos assassinatos, traições, venenos e enforcamentos que os indivíduos desencadeiam na luta por poder. Foi necessário o desenvolvimento da ordem legal burguesa, com a lei imposta a ferro e fogo, para, finalmente, pôr-se um fim à brutalidade endêmica.

Nessa medida, o aparecimento de um estado unificado, centralizado, $e$ a criação de um sistema de leis mais ou menos universal contribuíram bastante para babituar os homens a formas mais civilizadas de comportamento. Até certo ponto, foi essa a tarefa da cidade-estado constitucional; em geral, porém, foi a monarquia absoluta que iniciou e realizou esse processo, espalhando o poder da lei com o fogo e a espada (HELLER, 1982, p. 129, grifo do autor).

As relações burguesas e o dinheiro liquidavam os antigos valores e a vida acabava por ser dominada pela brutalidade da acumulação primitiva; em lugar da solidariedade da família e da lealdade dos amigos, tornam-se ocorrências cotidianas a traição, a lisonja, a denúncia, a hipocrisia e o cinismo. É disto que trata Maquiavel ao relatar a corrup̧̧ão social que assolava os povos europeus - a Itália em grau acentuado. As crescentes desigualdades de riqueza se acentuavam à medida em que 0 desenvolvimento burguês progredia - ou seja, à medida em que uma ética de procura incessante pelo dinheiro se generalizava - explicitando, a um só tempo, a degenerescência das morais e, diante disso, o esgotamento e colapso das formas de governo em moldes antigos.

As cidades-repúblicas do Renascimento foram edificadas a partir de um movimento geral de recuperação da antiguidade - no qual, em termos políticos, Roma segue, na análise de Maquiavel, como o grande referencial de vida social sadia. Em seus Discursos enaltece as "morais sãs", não deixando de enfatizar que sua existência está intrinsecamente vinculada às condições próprias das comunidades republicanas sólidas. Portanto, realidades baseadas numa igualdade relativa de riqueza - entre os estratos dirigentes, certamente - que ainda se conduzem por uma ética comunitária. A pólis renascentista está diante da dissolução da moral e da política tradicionais. A "vida comunitária" está em processo de desintegração final e a corrupção social é a confirmação mais feroz da extinção da comunidade. Maquiavel não só oferece um retrato fiel das condições sociais de sua contemporaneidade como se rende às exigências dos novos tempos. Compreende bem que a não adaptação da política e da ética à nova situação significaria a ruína da sociedade. 
Note-se que o comportamento humano que imprime civilidade à vida social está intrinsecamente vinculado à politicidade. Agir conforme a moral, ser civilizado, são atributos que o homem só adquire mediante a atuação de uma força externa que seja capaz não só de refrear seus baixos instintos como condicioná-los a boas ações. De modo que "Quem [quer que] considere as coisas presentes e antigas verá facilmente que são sempre os mesmos os desejos e os humores em todas as cidades e em todos os povos, e que eles sempre existiram." (MAQUIAVEL, 2007a, p. 121). E o reconhecimento de uma natureza bumana, constante e permanente ao longo dos tempos, não revela nada muito generoso.

Assim, "quem estabelece uma república e ordena suas leis precisa pressupor que todos os homens são maus e que usarão a malignidade de seu ânimo sempre que para tanto tiverem ocasião [...]” (MAQUIAVEL, 2007a, p. 20). Na visão de Maquiavel, os homens possuem, por natureza, tamanha ambição que é impossível de ser satisfeita. Esta disparidade entre apetites insaciáveis e capacidade de satisfação limitada é uma condição que, caso não seja refreada, pode levar os indivíduos a disputas altamente destrutivas (MAQUIAVEL, 2007a, p. 113).

\section{CONDICIONANTES HISTÓRICAS: LIMITES E POTÊNCIAS NA ANALÍTICA DE MAQUIAVEL}

A maldade natural ou o egoísmo universal identificado por Maquiavel, na verdade constituem a essência dos homens em uma época bistórica determinada. As ilimitadas possibilidades de adquirir riqueza, sucesso, fama ou de alcançar o poder a qualquer custo, são algumas das aspirações mais comuns que o capitalismo despertou nos homens do Renascimento. A concorrência, bem se sabe, isola os indivíduos; 0 egoísmo, na incessante luta pela satisfação dos interesses pessoais, há também de demarcar o caráter das relações interpessoais, compondo um quadro social bem particular.

Que Maquiavel universalize uma particularidade histórica é algo que se pode objetar com fundamento. No entanto, esta constatação não pode ser pretexto para um descarte ligeiro de suas formulações. Estamos diante de uma limitação histórica do período renascentista que ainda não dispunha das noções de História ou de autocriação do homem, no sentido de uma percepção do desenvolvimento histórico autêntico. Apesar de o tempo e o espaço terem sido humanizados e o infinito ter se tornado a realidade social, o movimento é cíclico e não se apreendem as alterações de épocas passadas e presentes, bem como as perspectivas futuras, num desdobramento em sentido espiral. 0 mundo é reconhecido como produto da ação humana, mas a humanidade não é apreendida em seu movimento de autoconstrução. 
Ao escrever seus Discursos, Maquiavel explicita sua convicção quanto à necessidade de haver verdadeiro conhecimento das histórias, mesmo porque "se o céu, o sol, os elementos, os homens tivessem mudado de movimento, ordem e poder, distinguindo-se do que eram antigamente", não haveria utilidade alguma em tal empreitada (MAQUIAVEL, 2007a, p. 67). A noção de repitibilidade cíclica leva-0, inclusive, a prescrever que é válido conhecê-las com a finalidade de imitá-las. Em termos políticos, seja na estruturação dos Estados ou na resolução dos litígios, quando quem governa negligencia ou não entende este preceito de buscar amparo nos remédios já usados, devido à semelhança dos acontecimentos, "segue-se que sempre se veem os mesmos tumultos em todos os tempos" (MAQUIAVEL, 2007a, p. 121). Vide o estado de degeneração social que assolava, então, o continente europeu - diria Maquiavel.

Certamente que a indignação de Maquiavel diante do declínio das morais na Itália, em Florença particularmente, desdobrou-se num programa político - um problema geralmente apresentado em termos de dois rumos alternativos:

Ou voltar à velha pólis e à sua ética comunitária, ou então rejeitar completamente o ideal da pólis e progredir no sentido da criação de uma monarquia absoluta unificada na Itália, aceitando a situação ética que 0 capitalismo contemporâneo trouxera e, além disso, levando-a até uma conclusão coerente (HELLER, 1982, p. 256).

No entanto, ressalta A. Heller, tornar excludentes e incomunicáveis as duas motivações pode significar a absolutização de um dos lados, onde Maquiavel é visto ou "exclusivamente [como] um advogado da monarquia absoluta e, além disso, o apóstolo de uma ética burguesa cínica, do "maquiavelismo político"” ou teremos as análises daqueles que "apenas viram o republicano plebeu que (como Rousseau, por exemplo pensou) tratou o tema do Príncipe de maneira puramente satírica" (HELLER, 1982, p. 256). E aqui nos reencontramos com a indicação analítica sugerida no início da discussão, a qual, ao mesmo tempo em que reconhece a modernidade da análise de Maquiavel de sua contemporaneidade - que desnuda a generalização da corrupção social e 0 aniquilamento das heranças civis e cívicas de molde antigo -, não deixa de explicitar que a solução proposta segue pautada pela recuperação do passado perdido. De outro modo: diante da exigência de uma nova legalidade que reorganize e reponha a sociabilidade, a referência para recriar o Estado segue sendo, em última instância, a reposição do bem comum como télos, nos moldes da antiga República romana.

Ao sintetizar a História de Florença, Maquiavel (2007b) explicita seu juízo negativo sobre a república florentina de então. Não hesita em recorrer ao absolutismo com o claro objetivo de reciclar (ou refundar - no sentido que ele mesmo coloca da importância do retorno às origens) a sociedade a partir da instauração de uma nova legalidade que, através da força e da astúcia, não só impediria o colapso social como ainda seria 0 indutor de relações mais positivas entre os indivíduos. Sua análise do 
presente é realista, seu instrumento de intervenção é moderno, mas seu verdadeiro télos emana do passado: a corrupção exige a imposição da lei a ferro e fogo pela mão régia do absolutismo, na tentativa idílica da restauração do bem comum.

A superação da ameaça de desintegração demanda a intervenção absolutista na imediaticidade; após a restauração social de sua condição degenerada, torna-se possível um poder equilibrado - ou a forma mista de governo em sua recuperação da vertente romana. Maquiavel não trabalha com a eliminação total do conflito social, dada a própria convicção que tem do caráter humano. A sociabilidade sadia consiste, portanto, numa equação eficaz quanto aos modos de contê-los e controlá-los. E é a consideração da dimensão pública que mantém equilibrada a ambição de riqueza e poder. 0 interesse coletivo - ou o bem da República - é, pois, condicionante da "boa e justa riqueza", da vida em liberdade, onde as diferenças convivem em harmonia e concórdia. Assim, Maquiavel denuncia e rejeita o presente corrompido, constatando a desagregação moderna, mas simultaneamente oferece uma resolução extraída do passado, numa clara tentativa de repor a vida comunitária, erigindo uma tematização que é puro amálgama das forças pulsantes em sua época.

Agnes Heller chama atenção para a irregularidade que caracteriza 0 desenvolvimento do conceito de homem e o conceito de sociedade. Afirma que tanto na Antiguidade quanto no Renascimento a reflexão sobre 0 homem era, fundamentalmente, um problema ontológico: "em ambos os casos a pergunta 'Como é o homem?' se confundia com o problema '0 que é o homem?'. A sociedade, no entanto, não se põe como categoria ontológica. 0 conceito explícito de sociedade surgirá muito posteriormente, uma vez que é produto do desenvolvimento capitalista. O que caracteriza o conceito de sociedade é, segundo a autora, sua identificação com o conceito de Estado. E isto é válido tanto para a Antiguidade quanto para o Renascimento, já que os pensadores renascentistas, neste aspecto, retomaram em grande medida aquela tradição: "interpretou os acontecimentos na sociedade como sendo primeiramente e essencialmente acontecimentos políticos". É certo que alguns fenômenos especificamente sociais, cuja existência era independente do Estado, foram objeto de reflexão tanto naquela (quando, por exemplo, Aristóteles discute a troca de mercadorias) quanto nesta época mais recente (ver a análise de Maquiavel sobre a revolta dos Ciompi, onde o conflito de classes é tratado como controvérsia entre ricos e pobres, e não como exclusivamente uma luta pelo poder). 0 importante, no entanto, é que "a estrutura social como um todo manteve-se sinônima da estrutura de estado".

Interessante também é enfatizar que a ideia de futuro, como uma perspectiva envolvendo uma transformação substancial do presente é algo que remete aos tempos em que 0 capitalismo começa a surgir. Até então as sociedades orientaram-se para 0 passado, onde o futuro aparecia, no geral, como mera continuidade e repetição do passado. Apesar de algumas vias possíveis de conduzir à objetivação do capitalismo 
terem sido interrompidas por limitações não superadas (como no caso italiano ou espanhol), a evolução da técnica e dos meios de produção progredia em ritmo acelerado por toda a parte durante o Renascimento. E logo se evidenciaram as tensões entre 0 desenvolvimento das forças produtivas e das relações sociais, com a agudização das contradições sociais e morais próprias desta nova sociedade em formação. É nas perspectivas mais otimistas quanto aos frutos do desenvolvimento técnico que surge a orientação para o futuro - a qual, no entanto, fica restrita no sentido do futuro tecnológico, inexistindo qualquer expectativa em relação ao desenvolvimento da sociedade, no sentido do futuro social ou de uma sociedade 'diferente' no futuro em comparação àquela do país mais desenvolvido e explicitamente burguês, a Inglaterra. No estudo da estrutura da sociedade, portanto, não era o futuro que dominava. Assim,

0 presente era ou simplesmente descrito ou quando muito analisado do ponto de vista de qual a ação imediatamente necessária (como em Maquiavel), ou ainda medido em função de algum ideal. A atitude para com o presente daqueles que escreviam sobre a sociedade era, portanto, determinada pela Realpolitik ou por um ideal. Não existia ainda uma "perspectiva social" (HELLER, 1982, p. 158, grifo do autor).

Poderíamos sintetizar o Renascimento, neste aspecto, como uma época já com uma perspectiva técnica, mas sem qualquer perspectiva social global. 0 evolver histórico mostra que a criação de uma sociedade "nova" e "melhor" não constituiu um objetivo dos homens do Renascimento, mas sim será uma visão que se colocará como determinante nas ações dos homens do Iluminismo. 0 decisivo consiste, no entanto, em evidenciar o caráter não bistórico que perpassam esses tempos. Nem um pensamento bistórico nem um pensamento anti-histórico, para evitar extremos que imputam atributos extrínsecos às possibilidades do período em questão. Evidentemente é suscetível que haja algo de não histórico numa época em que a própria noção de historicidade ainda não se desenvolvera. E, como é próprio das contradições de uma transição histórica, os indivíduos oscilavam cotidianamente entre orientações para o passado e para o futuro: seus passos eram guiados pelo presente apesar de o ideal, não raro, encontrar-se no passado.

Mas o orientar-se para o "autêntico passado" muito rapidamente mostrou-se como uma impossibilidade diante das rápidas mudanças na técnica e nas condições sociais. 0 indivíduo que não se mantivesse pari passu às exigências do presente não subsistiria. A adaptação constante aos novos tempos se impunha em todos os aspectos da vida para aqueles interessados em não perder o ritmo da história. As inovações técnicas assim determinavam as relações produtivas e mesmo a produção do setor artístico, bem como nas relações humanas o indivíduos não mais se pautavam pela tradição familiar (a mesma moral, a mesma maneira de viver, o comportamento, o vestuário), que 
deixava de ser referência na medida em que as formas tradicionais de vida se desintegravam. 0 político de Maquiavel é a expressão mais radical dessa exigência.

Nesse sentido, mesmo tendo o passado como ideal, a ação individual era motivada por essa necessidade de manter-se em consonância com o presente. E é particularmente desta atitude que irá se desenvolver - na vanguarda das respectivas áreas - um certo tipo de orientação para o futuro, preocupando-se com as possibilidades do que existirá.

Quando consideramos o caso italiano, a pólis florentina em especial, verifica-se que 0 processo de acumulação primitiva interrompeu-se antes de poder romper os limites da cidade-estado. Esta particularidade fez emergir uma realidade onde convivem dois princípios antagônicos: enquanto no domínio econômico o desenvolvimento tendia a uma expansão sem limites (é próprio do capital destruir todos os limites comunais que se lhe interpõem), rumo ao infinito, na estrutura política ainda prevaleciam limites fixos. A categoria da "medida", herança direta das sociedades de tipo comunal, no sentido de limitações sociais em sentido simultaneamente ético, permanecia como norma real de comportamento na vida política, onde o bem da república ainda era referência para as ações individuais. No que se refere à busca pelo lucro, na satisfação dos interesses pessoais, não havia limites, mas na atividade política existia de fato uma "medida".

Em certo sentido Maquiavel incorpora essa contradição de um tempo em que nem o bistoricamente velho ainda subsistiu integralmente e nem o bistoricamente novo triunfou por completo. Sua análise volta-se às novas exigências no plano político e apesar de não haver um raciocínio claro das determinações econômicas que levam a tal configuração, ainda há percepções das mudanças sociais que impõem uma nova postura política. 0 absolutismo é o instrumento através do qual se põe a possibilidade de resgatar a sociedade da degenerescência moral que a assola, nitidamente ligada à crescente desigualdade de riqueza que está por destruir os antigos laços comunais. Mesmo diante da força e da astúcia que se exige dos governantes, ainda ecoam os vestígios do bem comum - formulação consonante com o caráter "intermédio" do Renascimento, que põe uma formação social "a meio caminho" das antigas repúblicas das cidades-estado, por um lado, e do Iluminismo, por outro.

0 Renascimento marca o próprio "nascimento da individualidade", marca 0 momento em que os indivíduos começam a tornarem-se conscientes de sua própria subjetividade. A concepção do mundo como feito de indivíduos determina as perspectivas teóricas surgidas a partir de então. E não raro a autopreservação irá ser entendida como a determinação primária do comportamento humano. Nesse sentido, temos que

A sociedade, o status civiles, acaba igualmente por surgir como um conjunto de elos ligando unidades individuais que se assemelham entre si. A 
commiseratio é o motivo que nos incita à atividade social; "pôr-se no lugar dos outros" transforma-se no ponto psíquico de partida para a compaixão social. Podemos ver aqui o início do moderno princípio burguês do egoísmo, a fonte antropológica de todas as teorias do contrato social. Tratava-se da primeira tentativa - mesmo que apenas num sentido - de construir a sociedade a partir dos "átomos" constituídos pelos homens individuais. No início, portanto, não estava a sociedade, mas sim o homem (HELLER, 1982, p. 169).

0 indivíduo isolado, egoísta, como ponto de partida da reflexão situa, assim, Maquiavel como precursor por excelência de toda a tradição contratualista que se desdobrará nos séculos seguintes. A política assume tamanha importância para Maquiavel (2007a, p. 14-15) que, em sua análise, há correspondência entre 0 surgimento do Estado e do Direito com a própria civilização. Desta maneira, ao destacar a condição dos homens nos primórdios dos tempos, Maquiavel elabora um breve esboço do contrato social, indicando que os homens, dantes isolados, se reúnem em busca de segurança, submetendo-se a leis que os permitam a vida em sociedade. Está convicto de que "só o poder dá segurança aos homens", indicando que somente a regulação jurídica das relações dos indivíduos pelo Estado confere as condições necessárias para uma vida civilizada, ou seja, como os homens constituem um perigo para si próprios, qualquer ação virtuosa praticada é produto da imposição da lei - força de condução que só o Estado possui.

\section{PARA UMA CIÊNCIA DA POLÍTICA}

Durante o Renascimento a experiência do cotidiano constituiu o ponto de partida dos mais variados tipos de reflexão, com especial atenção para a artística e a científica. Em grande parte, foi a partir da observação da experiência cotidiana e de sua subsequente generalização que novas ciências surgiram - como é o caso da ciência da política com Maquiavel. Há certo consenso em se admitir que a formulação dada por Maquiavel à questão política se caracteriza por reconhecê-la como atividade autônoma, com princípios e leis próprios - distintos e independentes, portanto, daqueles da moral e da religião. Polêmico, pois, é o significado deste fundamento no conjunto de sua produção teórica. É comum, por exemplo, a referência ao cinismo e ao oportunismo que derivam desta autonomização e que vão impregnar a ação política ou o maquiavelismo político como, genericamente, bastante se difundiu. No entanto, como afirma A. Gramsci, com seus escritos Maquiavel "visa apenas e concretamente a mostrar como deveriam atuar as forças históricas para se tornarem eficientes" (GRAMSCI, 2007, p. 36). 
É somente no Renascimento que a política irá se tornar uma esfera autônoma em relação às normas gerais da vida social. A política como técnica, como um ofício, tem como uma de suas pré-condições a divisão social do trabalho capitalista. É somente aí, portanto, que as categorias separadas de "político" e de uma "atividade política" (no sentido de capacidades e deveres distintos, inclusive com uma maneira própria de pensar) independentes das demais esferas do social começam a surgir na vida e no pensamento. E surgia com tal imperiosidade que este tipo de atividade política profissional muitas vezes era a mediação decisiva em questões cujo cerne era a própria "sobrevivência social". Isto quando consideramos

[...] 0 ritmo mais acelerado da história, que exigia decisões cada vez mais rápidas, adaptadas a novas situações, e o declínio da orientação para 0 passado e a crescente orientação para o futuro, que tornaram incertos a tradição e o precedente e exigiam novos recursos individuais. Pelo menos igualmente importante, porém, era 0 aumento em proporção geométrica dos contatos internacionais e dos conflitos entre nações, nos quais a tomada de decisões tornava necessários inúmeros tipos específicos de conhecimento - e os diferentes tipos de conhecimentos tornavam-se cada vez mais numerosos à medida que o tecido econômico e político da sociedade se tornava mais complexo: uma política nacional que, aqui e ali, se estava já a transformar numa política mundial. E quanto mais vasta era a unidade que a atividade política procurava e realizava, mais pesadas se tornavam as consequências; quanto menor era o papel desempenhado pelo precedente na tomada de decisões, mais dependiam os resultados da responsabilidade pessoal dos políticos (HELLER, 1982, p. 276).

Um dos aspectos decisivos das reflexões de Maquiavel trata precisamente da necessidade desta nova técnica - principalmente numa Itália tão carente de verdadeiros estadistas. Sua análise da política se desdobra numa época e num lugar em que, de fato, o Estado burguês, em seus contornos iniciais - a monarquia absolutista -, nem sequer se desenvolvera. No entanto, suas conclusões a partir da investigação das leis da ação política são fundamentais: a racionalidade política é de outro tipo, sua forma de pensar e de conduzir as ações são distintas, bem como sua ética e seu modus operandi não deixariam de ser diferentes daqueles encontrados na vida de indivíduos que não exercem essa atividade específica.

A percepção global da situação e a prática global individual estão intrinsecamente ligadas, sendo que tal conhecimento e tal prática políticos dirigem-se para o fim como um todo. Ser bem sucedido nos objetivos propostos constitui uma máxima em política. É a partir da análise das consequências que Maquiavel avalia 0 valor de uma ação política. Ou seja, a ação política genérica tem como principal critério moral as consequências, de modo que o êxito nas ações desencadeadas constitui 0 máximo valor na ética política. Os resultados positivos, porém, decorrem da correção do 
conhecimento e da prática políticos. Em segundo plano, como aspectos subordinados àqueles, emergem as questões relativas à manipulação política e a ética política. E em Maquiavel a essência da manipulação nada mais significa que dispor de todos os meios necessários à implementação prática do conhecimento político, tudo aquilo exigido para atingir-se com êxito a finalidade previamente estabelecida.

Em síntese, sua teoria dos meios e dos fins tem como conteúdo que nenhum dos meios - por mais violento ou inescrupuloso - deve ser rejeitado se for necessário para se obter o resultado desejado. Assim, em sentido político, um instrumento intermédio é bom ou mau na medida em que se revela um meio adequado ou inadequado, respectivamente, à concretização de um fim. E muitas vezes aquilo que na moral tradicional é condenado faz-se necessário em política, constituindo-se como meio mais adequado. Deixando de ser necessário, cessa também sua condição de meio adequado e deve, por conseguinte, ser rejeitado.

\section{POLITICIDADE MODERNA: EGOÍSMO UNIVERSAL E PODER}

Não há, portanto, apologia à manipulação de forma indiscriminada. Em política, a prioridade é determinada pelos êxitos dos fins. A virtude política consiste precisamente no correto discernimento da utilidade dos meios na efetivação de um fim; meios estes, aliás, em constante mutação devido às incessantes transformações socais. E a prudência, em política, envolve precisamente esta correta avaliação quanto às exigências impostas pelos novas situações e sua consequente adaptação a elas, assegurando eficiência nos resultados das empreitadas políticas.

E a manipulação política torna-se indispensável - isto é, uma necessidade imprescindível - dada a generalizada "corrupção" dos homens. De fato, a hipocrisia se desenvolveu a tal grau nesta época que se tornou um problema social e ético de alcance mais ou menos universal. A luta competitiva que motivava os homens em todas as instâncias da vida - do econômico à ciência e à ideologia - marcou o comportamento individual com toda sorte de simulações e dissimulações visando a "preservação" de interesses particulares. E numa realidade de homens egoístas, onde geralmente "0 outro" era visto como um obstáculo para a concretização de seus próprios planos e intenções mais profundos - e que deveria, portanto, ser "superado", quando não eliminado - não surpreende que na atividade política a lógica da concorrência tenha surgido de maneira ainda mais feroz.

Agregue-se que em tal época de intensas mudanças, o conhecimento dos bomens - tão essencial na ponderação entre as possibilidades de ação - tornou-se mais complexo que no antigo sistema de ordens feudais. Antes havia condições para uma certa previsibilidade quanto às ações e reações dos homens, dado que se configuravam 
por um padrão mais ou menos fixo de comportamento, ligado à ordem social a que 0 indivíduo pertencia. Mesmo as situações mudaram de padrão, deixando de possuir uma "estrutura" mais ou menos determinada, configurando-se agora como inesperadas e imprevisíveis. 0 peso de caráter individual aumentava sobremaneira e só por intermédio do conhecimento do caráter humano, mesmo que aproximadamente, é que se poderia incorrer a algumas antecipações.

$\mathrm{E}$ as dificuldades seguiam em grau crescente. A nova divisão do trabalho nos moldes capitalistas e a abertura da hierarquia social liquidavam as determinações por nascimento, possibilitando que uma mesma pessoa ocupasse diferentes degraus na escala social, cada uma dos quais, por sua vez, exigindo o desempenho de um "papel" específico. E os comportamentos individuais variavam em função dos diferentes papeis sociais por ela desempenhados. À medida que todas as comunidades foram sendo dissolvidas pelo capitalismo nascente, a afirmação do homem era cada vez mais consolidada pela mediação da posição por ele ocupada na divisão social do trabalho. Não foi de outro modo que o estatuto econômico suplantou a bumanidade como comunidade como norma universal, consumando a divisão do homem em indivíduo e papel. Um exemplo que não pode ser desconsiderado quando é posta em evidência a atenuação do elo entre as personalidades dos homens e as funções por eles exercidas na sociedade, consiste em mencionar que foi a separação entre o cidadão e o burguês, que antecipou a clivagem entre a vida pública e a vida privada.

A bipocrisia como forma de ser, implica que o enlear os homens com a dissimulação, a fraude, o embuste e a mentira,

[...] refere-se não só à maneira desonesta de ganhar a afeição dos outros, mas a todos os tipos de estratagemas com que os homens podem exercer poder sobre outros. Com efeito, a hipocrisia ativa do Renascimento tinha como verdadeiro objetivo destruir o outro ou submetê-lo ao nosso próprio poder (HELLER, 1982, p. 171-172).

A realidade social trouxera a problemática do poder ao primeiro plano; uma consequência apenas necessária da competição por alcançar um estatuto entre indivíduos egoístas impulsionados pelo princípio do "êxito". É reconhecendo a primazia da disputa pelo poder como força motriz das relações humanas que Maquiavel atualiza a reflexão da política, configurando-a em seu sentido moderno, que tem no poder 0 centro prioritário da discussão. Nesse sentido, pode-se afirmar que "Maquiavel examina, sobretudo, as questões de grande política: criação de novos Estados, conservação e defesa de estruturas orgânicas em seu conjunto; questões de ditadura e de hegemonia em ampla escala, isto é, em toda a área estatal" (GRAMSCI, 2007, p. 22).

Afirmamos que a necessidade da manipulação política decorre do egoísmo universal que caracteriza a natureza humana. Podemos indicar também que, mesmo 
não ficando restrita à esfera da manipulação, a violência terá seu uso justificado pelo mesmo fundamento. Lembramos que o extermínio físico, o uso radical da violência como meio necessário, é um preceito admitido quando está em questão a eliminação de inimigos políticos, pois em caso algum Maquiavel reconhece um fim que permita justificar como meio "adequado" o genocídio da população em geral. De qualquer modo, é Maquiavel quem inaugura a categoria do "mal necessário" em função da vil natureza dos homens. Ressalte-se, ainda, que o emprego de métodos moralmente condenáveis não era concebido pelo pensador florentino como algo a ser empregue de modo constante e regular, mas apenas como um meio temporário de assegurar com firmeza o poder. Estas se enquadram no rol das "crueldades bem cometidas", em oposição àquelas cometidas indevidamente.

[As crueldades] bem usadas se podem chamar aquelas (se é que se pode dizer bem do mal) que são feitas de uma só vez pela necessidade de prover alguém à própria segurança e depois são postas à margem, transformandose 0 mais possível em vantagem para os súditos. Mal usadas são as que, ainda que a princípio sejam poucas, em vez de extinguirem-se, crescem com o tempo. Os que observam a primeiras destas linhas de conduta podem, com a ajuda de Deus e dos homens, encontrar remédio às suas consequências. Aos outros é impossível manter-se. É de notar-se, aqui, que, ao apoderar-se dum Estado, o conquistador deve determinar as injúrias que precisa levar a efeito, e executá-las todas de uma só vez, para não ter que renová-las dia a dia. Deste modo, poderá incutir confiança nos homens e conquistar-lhes 0 apoio beneficiando-os (MAQUIAVEL, 2000, p. 48).

A questão da ética política é muito mais ampla e complexa. Está em curso, nos meandros da Renascença, uma contradição interna entre a moralidade abstrata e a ética social real. Concomitantemente à implosão do sistema feudal, os conjuntos fixos de valores perderam sua validade. As ações demarcadas por virtudes abstratas em todos os tempos e lugares explicitam-se como um impossibilidade; Maquiavel declarou que tal situação, mais do que ser contrária às exigências da época, o era à própria "natureza humana". Maquiavel não nega a contradição que se desnuda em seu tempo entre 0 dever e as possibilidades reais de agir conforme tal dever. Pelo contrário, reivindica que 0 agente político seja consciente de suas responsabilidades. Como o raio de ação das decisões políticas é mais amplo do que o circunscrito pela ação dos indivíduos comuns, tanto maiores são as responsabilidades dos homens públicos, de modo que suas atribuições the imprimem a condição de agir "acima da lei e da moral" que regem as demais individualidades. As consequências constituem o critério par excellence da atividade política - para a qual a realidade muitas vezes só deixa a escolha entre 0 menor mal possível. A virtú do estadista consiste em fazer as melhores escolhas, dentro das possíveis, para domar os caprichos da fortuna e, assim, concretizar os fins propostos. São os resultados das ações, na precisa adequação entre fins e meios, que distinguirá 0 
bom do mau político - julgamento que, por conseguinte, decorre da análise de situações concretas (MAQUIAVEL, 2007a, p. 41-42). É desta forma que Maquiavel separou, em sua concepção global, o sistema de valores abstratos da prática política concreta, com clara ênfase na superioridade dos resultados desta última como valor superior, pois:

[...] quando se delibera sobre a salvação da pátria, não se deve fazer consideração alguma sobre o que é justo ou injusto, piedoso ou cruel, louvável ou ignominioso; ao contrário, desprezando-se qualquer outra consideração, deve-se adotar plenamente a media que lhe salve a vida e mantenha a liberdade [do Estado] (MAQUIAVEL, 2007a, p. 443).

Maquiavel aceita o caráter contraditório do progresso, numa época em que todas a medidas de progresso social eram, necessariamente, contraditórias em termos morais. Inúmeras vezes os vícios são os meios mais eficazes para se atingir um objetivo ético - cuja admissão é restrita, obviamente, a enquanto persistir sua utilidade ou condição de mal necessário. Maquiavel, apesar de oscilar entre a ação revolucionária e a reformista, é inequívoco que, em todos os casos, orienta-se para a transformação do mundo.

\section{ESTADO E A QUESTÃO DA VIOLÊNCIA}

Aqui devemos nos reportar novamente à questão da violência. A unificação territorial e política foi fundamental para 0 desenvolvimento do modo de produção regido pela lógica do capital, de modo que seu desenvolvimento foi levado a cabo naqueles países onde a monarquia absoluta atuou como força auxiliar na destruição das barreiras contrárias à produção burguesa. A recorrência à violência como meio necessário à manutenção ou à instauração do poder era um problema que emergia onde quer que se observasse o curso dos acontecimentos. É ao não uso da violência que Maquiavel computa, por exemplo, a causa da queda de Savonarola na Itália. Da mesma forma, reconhece que tanto na França quanto na Inglaterra foi por meio da mão régia do absolutismo que a ordem social fora estabilizada. Assim, é certo que

Antes que os grandes "legisladores" pudessem aí nascer, foi primeiro necessário exterminar os seus rivais pelo fogo e pela espada - ou seja, a violência. No seu país, Maquiavel alimentou a expectativa de uma nação italiana unificada sob a forma de uma monarquia absoluta moderna. Para criar - particularmente à luz dos interesses muito divergentes dos estados mais pequenos e do Papado - era necessário uma mão forte, um homem que não respeitasse nada nem ninguém ao procurar realizar os seus objetivos. Só depois de realizada à força a unidade da Itália se poderia iniciar a grande obra de "legislação", assim como o "retorno" do povo às suas próprias origens (HELLER, 1982, p. 284). 
É o mesmo que assevera A. Gramsci quando afirma que as assertivas desenvolvidas em História de Florença, por exemplo, "devem efetivamente servir como uma análise das condições reais italianas e europeias das quais derivam as exigências imediatas contidas em $O$ Príncipe" (GRAMSCI, 2007, p. 31), numa clara explicitação do vínculo entre as necessidades materiais e as proposições ideais. Nos projetos políticos apresentados, reconhece que opríncipe,

Sua "ferocidade" está voltada contra os resíduos do mundo feudal, não contra as classes progressistas. 0 Príncipe deve por fim à anarquia feudal, e é isto que faz Valentino na Romanha, apoiando-se nas classes produtoras, comerciantes e camponeses [18]. [Evidencia-se, portanto,] o caráter militarditatorial do chefe do Estado como [aquele que] se requer num período de luta para a fundação e a consolidação de um novo poder [...] (GRAMSCI, 2007 , p. 29, grifo do autor).

Antonio Gramsci recorda que, em certas análises, o Príncipe figura como 0 tratado da ditadura (momento da autoridade e do indivíduo) e os Discursos como tratado da hegemonia (momento do universal e da liberdade). Aqui, novamente, a absolutização é problemática; mais correto, afirma Gramsci, seria identificá-los como tratamentos preponderantes. São momentos que não se excluem mutuamente e "Assim é justa a observação de que não há oposição de princípio entre principado ou república, mas se trata sobretudo da hipóstase dos dois momentos de autoridade e universalidade" (GRAMSCI, 2007, p. 22).

Quando refletimos sobre uma outra afirmação do mesmo autor, referente à "dupla perspectiva" na ação política e na ação estatal, é possível notar que para Gramsci, em consonância com as formulações de Maquiavel, que a política, em sua essência, comporte os dois momentos da autoridade e da universalidade, que preponderam de acordo com as exigências dos tempos. A ação política teria como matrizes, pois, "dois graus fundamentais, correspondentes à natureza dúplice do Centauro maquiavélico, ferina e humana, da força e do consenso, da autoridade e da hegemonia, da violência e da civilidade, do momento individual e daquele universal [...]" (GRAMSCI, 2007, p. 33). Esta análise é reiterada quando Gramsci compara as concepções de Maquiavel e J. Bodin que, juntamente com T. Hobbes, são considerados como os fundadores da ciência política moderna. É necessário considerar que:

Bodin funda a ciência política na França num terreno muito mais avançado e complexo do que aquele oferecido pela Itália a Maquiavel. Para Bodin, não se trata de fundar o Estado unitário-territorial (nacional), isto é, de retornar à época de Luís XI, mas de equilibrar as forças sociais em luta dentro desse Estado já forte e enraizado; não é o momento da força que interessa Bodin, mas o consenso. Com Bodin, tende-se a desenvolver a monarquia absoluta: o Terceiro Estado tem tal consciência de sua força e 
dignidade, sabe tão bem que a sorte da monarquia absoluta está ligada a sua própria sorte e a seu próprio desenvolvimento, que põe condições para dar seu consenso, apresenta exigências, tende a limitar o absolutismo (GRAMSCI, 2007, p. 31, grifo do autor).

\section{CONSIDERAÇÕES FINAIS}

Cassirer sintetiza, com sagaz ironia, que "Ainda em seu melhor momento, a política é sempre um intermediário entre a humanidade e a bestialidade" (CASSIRER, 1976, p. 279). Assevera, assim, a convicção de Maquiavel da potência positiva da lei como fonte geratriz da virtude moral e cívica, "pois que, pelo medo da punição, mantêm consigo os homens melhores e menos ambiciosos." (MAQUIAVEL, 2007a, p. 73). Mas:

0 que cabe e convém apontar, na esfera da problemática moral, que sempre envolve a leitura dos escritos de Maquiavel, é que este, exatamente por seu vigoroso realismo, esbarra praticamente, sem a tematizar, na verdadeira questão ética: como justificar atos necessários, eticamente impossiveis de serem justificados? Esta pergunta, cuja visibilidade antes de tudo se manifesta na esfera da politicidade, não apenas situa rigorosamente 0 problema da eticidade, mas aponta, em seus devidos termos, para a natureza e os limites da política e a sua excludência em relação ao mundo ético (CHASIN, 2000, p. 209).

Também é de J. Chasin a afirmação de que, em Maquiavel, política e natureza bumana são dois complexos ontológicos funcionalmente indissociáveis (CHASIN, 2000, p. 236-237), de modo que a importância do poder político é maximizado em razão direta à desqualificação do ser humano. A maldade natural, ou o egoísmo universal, é o fundamento irremovível em que se ancora toda a tematização política de Maquiavel. Referimos que a virtude por vezes verificada nos homens é puro efeito da lei porque, por natureza, o indivíduo é perverso: sua agressividade, seu egoísmo e sua ambição são tão perenes quanto as relações são conflituosas e a desunião é insuperável. Aliás, conhecer essa perversidade humana é condição para governar. Daí sua autorização para usar dos mesmos meios quando a situação assim o exigir. Importa que é pela coerção legal que a desumanidade dos bomens, a brutalidade bumana, é regulada e humanizada. Coação, pois a lei deve ser apoiada na força para garantir seus efeitos civilizatórios. 
Apesar de Maquiavel conferir peso inestimável à política, sua acepção revela 0 caráter limitado de sua intervenção ${ }^{2}$. Isso porque ela só produz efeitos comportamentais, sem ser capaz de alterar a índole humana: o medo da punição controla e restringe a perversidade humana, e por uma imposição externa torna o homem bom - uma característica que persiste enquanto e só o medo do castigo e o respeito às instituições permanecerem vivos nos corações dos homens. E é nesse sentido que a maldade natural é postulado, base e razão de ser de toda ossatura conceitual relativa à política. De modo que autonomia do poder e perversidade bumana são imprescindíveis na mesma proporção: Maquiavel afirma de modo irrestrito a soberania absoluta (acima da lei e da moral) pois todo indivíduo é um degenerado inato (CHASIN, 2000, p. 236).

Em termos históricos, é possível apreender que a caracterização do homem feita por Maquiavel traduz a "individualidade isolada" gestada pelo capital em seu nascedouro - daqueles indivíduos egoístas, cuja motivação é restrita à satisfação dos próprios interesses; uma individualidade apartada dos outros e posta contra estes em competição, cujo resultado não poderia ser outro que desdobrar-se em relações que refluem à animalidade. Cabe à política mediar e conduzir à humanidade. Modernidade esta que Maquiavel flagra em seu panorama inaugural. É ele também que retrata em primeira mão os primórdios do processo de autonomização e isolamentos modernos da política e do Estado, na tendência da ruptura com o próprio homem. Ao dessacralizar a política, ao encará-la em suas determinações terrenas, Maquiavel sintetiza a moderna entificação do poder e ratifica o surgimento do Estado verdadeiro. De modo que a este bomem desvalorizado, sozinho e depreciado, lhe restou como única possibilidade de ser a conjunção abstrata dos bomens na união imposta e ilusória do Estado.

\footnotetext{
${ }^{2}$ Particularmente isto traz à reflexão que a politicidade pode ser uma necessidade própria a períodos muito particulares, caracterizados pelo ainda baixo grau de desenvolvimento da humanidade. Em sentido moderno, a politicidade surge atada às necessidades de expansão do capital e de uma formação social incapaz de se autogerir e sustentar por suas próprias forças. É, pois, um atributo bistoricamente determinado - e não perene como sustenta a filosofia política tradicional. E a elaboração de Maquiavel abre caminho para a apreensão da própria natureza da política, de seus limites intrínsecos, de seu caráter de força social ativada não pelos melhores atributos dos homens e que tem na irresolução sua forma de ser. Ver J. Chasin (1999, 2000, 2009).
} 


\section{REFERÊNCIAS}

CASSIRER, Ernest. 0 mito do estado. Rio de Janeiro: Zahar, 1976.

CHASIN, José. A Ad Hominem: rota e prospectiva de um projeto marxista. In:

Ensaios ad hominem. São Paulo: Estudos e Edições Ad Hominem, 1999. Tomo III.

. Determinação ontonegativa da politicidade. In: Ensaios ad

bominem. São Paulo: Estudos e Edições Ad Hominem, 2000.

2009.

. Marx: estatuto ontológico e resolução metodológica. São Paulo: Boitempo,

GRAMSCI, Antonio. Maquiavel: notas sobre o estado e a política. Cadernos do Cárcere, Rio de Janeiro, v. 3, 2007.

HELLER, Agnes. O bomem do renascimento. Lisboa: Presença, 1982.

MAQUIAVEL, Nicolau. Discursos sobre a primeira década de Tito Livio. São Paulo: Martins Fontes, 2007a.

. História de Florença. São Paulo: Martins Fontes, 2007b.

. O príncipe. São Paulo: Nova Cultural, 2000.

MARX, Karl. Grundrisse. São Paulo: Boitempo, 2011. 